PS 2673

Ris W/s 



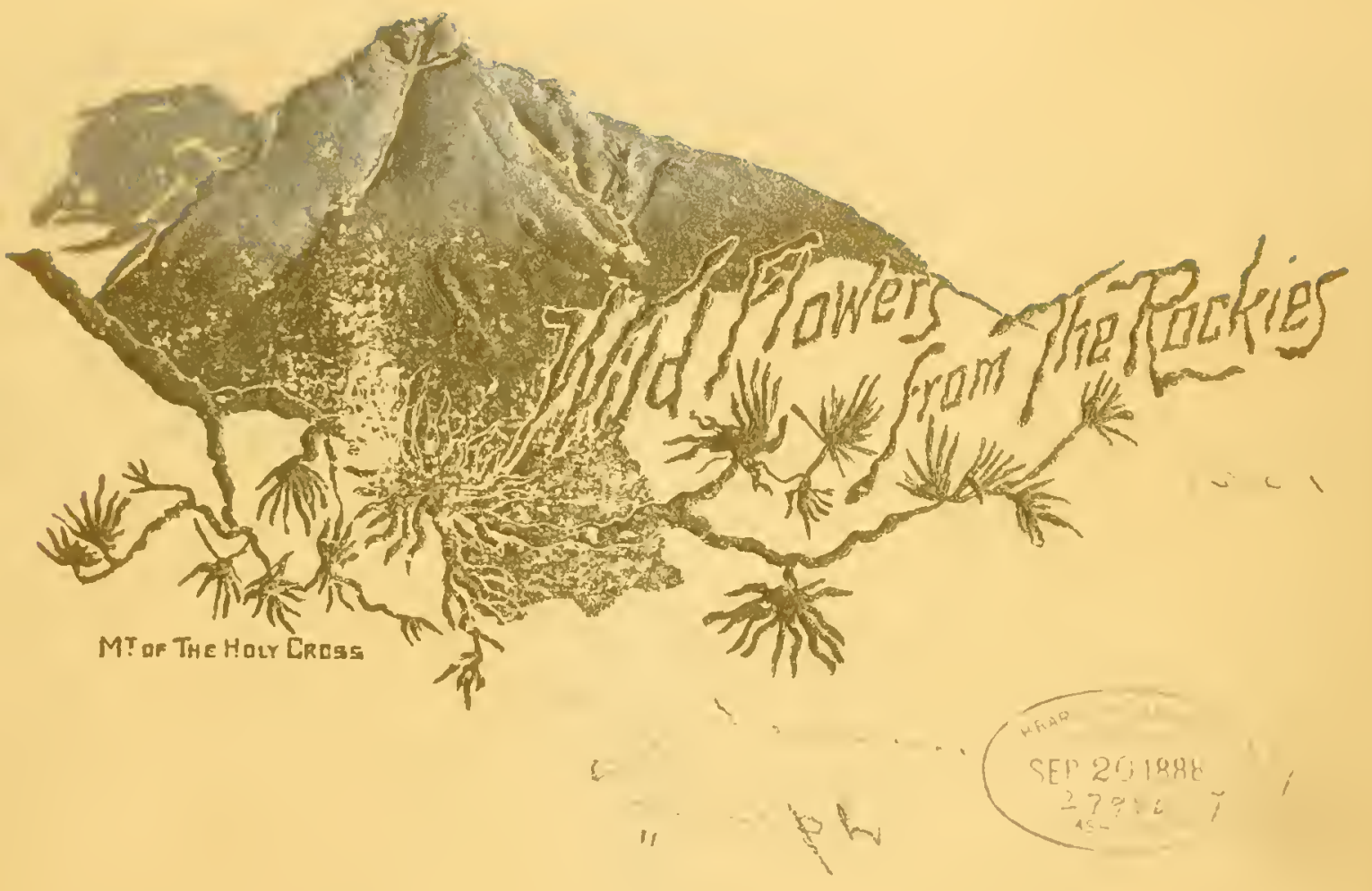


1. 


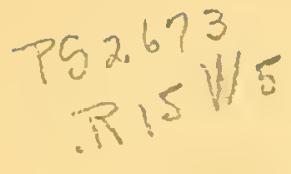

F R to the West, where the cloud uavies of the sky seemed to rest their zeels upor the earth, was a bark of something wondrously beantiful. The people of the Prairle, who saw it on every sundy day, said that it was the Rocky Mountains. That secured iupossible. Never were the clouds themselves less palpable. At every instaut one half expected to see the exquisite mass lift up and float away or break and vanish, like mist that rises above the tree-tops and is instantly dissipated by the morniag sun.

The main reason why the spectacle seemed so unreal and unsubstartial was that it defied both logic aud the senses. If it resembled auything substantial its features still stiggested only what was impossible, for it was like a stupendous mound of turquoise upon which was heaped miles of emeralds, covered at the top with pearls and diamonds, suggestiug crystal covered with SUCW.

All have seen a heavy bluck of purest ice through which a powerful light is shiuing, and have noticed the colors that the prisms of the ice derelop. Nothing clsc kilown to man will siggest how the Rockies looked that afterioou. Yet the thought of miles of clearest ice lighted up by the sun offers oviy a hint of the scenethe reality was teu-fold as beautifil and lovely.

Think then, o pampered seader, used to rolling through time and distance ia cushioned palace cars, what must have becu the effect of this sight upon our fathers, the Pioneers, as tliey jogred toward the Rockies in creaking, hot and dusty prairie schooucrs in the years agone! The sight gave every one new zest for his task of nation building. It was drink to the thirsty, food to the hungry, spurs to the bare of foot and a saddie to the rcary.

$\mathrm{Ah}$ ! but it was not only this. It was no illusion of a laud of pronise -10 dream that was to varisb wlien the mountaing vere reached. To evcry one the Rockies brought more thau they promised. In their vales ran crystal streams, 'neath their trees was cooling slade, fruits and berries rejoiced the waymcru bands, aud, while perfect rest was offered, the invigorating air inspired all with iucreased crergy.

To-day the Rocky Motutains still invite tic travcler-still reward him. The colcrs tliat distance lends them ranish at cloce approach, but ouly to reappear, with yet closer familiarity, in such a weaith of fluwers that one lalf suspects it was their blossum 3 that gare them the gaudy hues they showed. Flowers deck their inclined sides in great blocks of color and litter their terraces and woodlaud edges in variegated confusion. There is no difficult pass wliere they are not founa, no dusky gleu that does not harbor them, scarccly any height on wlich sume will not appcar to glad. den him who toils to reach the suramits. 


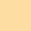




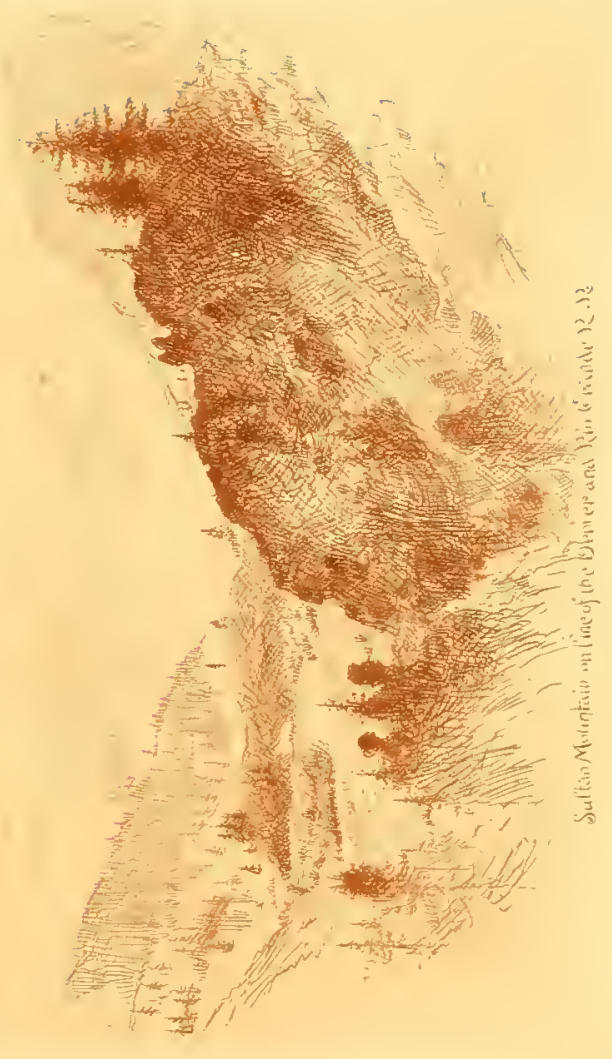





\section{The Making of the Flowers.}

- hail the fod Man-whom none praiese

Aso owning poet's Breast;

A Areamer thro' ?ong cuinter สays,

OWith oong and stozy blest.

อृุo' BRina to eruth, her book he scannea;

ब(j)o' Jeaf, Re tzied to fieaz.

otrange as his Rind the tales each band

passed on from lip to ear.

Hazkீ but to this, by sachemo grave

(D) sons of ohiefs made known,

ब0 show those ocions zute and orave

A pocuer beyona their own.

'อis Pegena told of primal day»,

OWh̨er Manitou, like clay,

बढ̨e grey zoci mountain shapes did zaiøe

ब0 ceiebrate Rif ency.

He was not pleased. The mountains bare

(O) Were Sieck cind dupl and grey.

He onatched a rainbow from the air,

एo use ito colors gay.

Gzumbling its Sazo, with chanted opell,

구으eir rasiani Guot he thzero,

Anส everyoshiere a Ran बful felp

A milpion flocu'rets grew. 


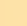




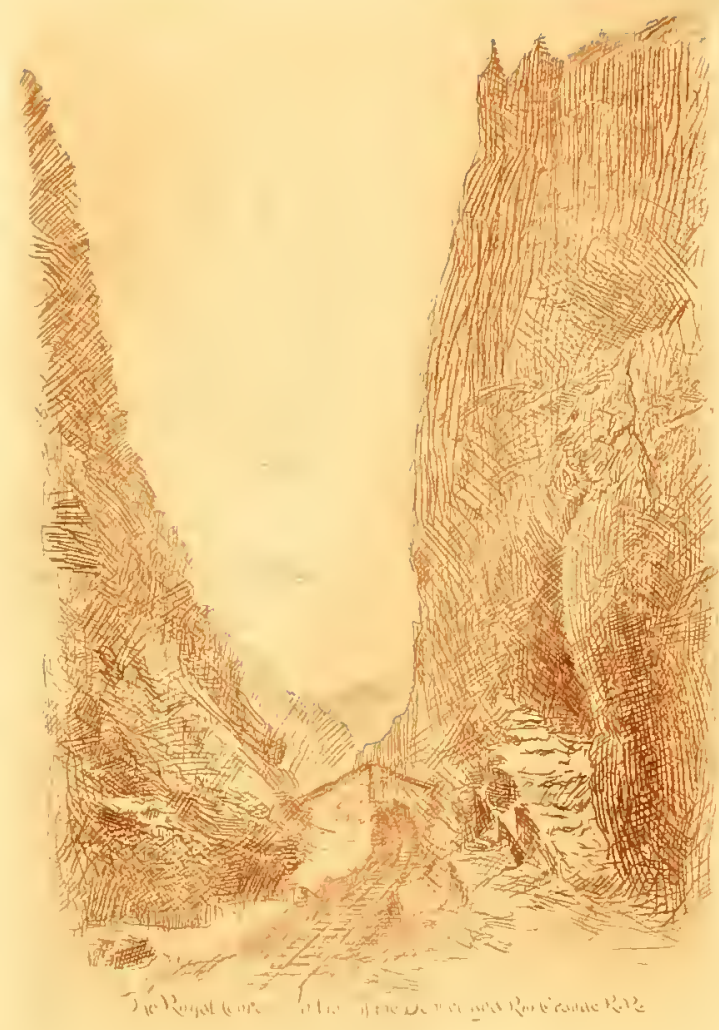



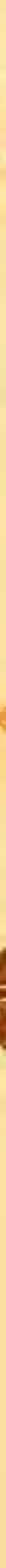
LIBRARY OF CONGRESS

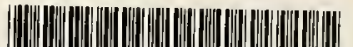

I. (I)

00161656586 